\title{
Slight damage of the great green bush-cricket (Tettigonia viridissima) (Orthoptera: Tettigoniidae) in some Hungarian maize fields
}

\author{
András Bozsik \\ University of Debrecen, Institute of Plant Protection, Debrecen, Hungary \\ bozsik@agr.unideb.hu
}

SUMMARY

\begin{abstract}
Characteristic cricket damage was observed in two maize fields in northern Hungary, at Máriabesnyö, a district of Gödöllö. The damage level of the two fields did not differ significantly and continual monitoring of field1 showed also a stable infestation level. T. viridissima nymphs and a female were found and observed as feeding on maize plants. The crickets must have disappeared after 18.07. because no more fresh damage was observed after this date. The chewing's number about on one and two \% of the examined plants amounted one and six a plant and their size was between one and eight $\mathrm{cm}^{2}$. This infestation was quite little and might have caused apparently no yield loss. Compared this damage of T. viridissima with former Hungarian experience, this was the usual negligible damage despite the explicit draught in July and August 2015. As regards the global warming, orthopteran damage may be more obvious in the future.
\end{abstract}

Keywords: Tettigonia viridissima, Tettigoniidae, maize, damage, Hungary

\section{INTRODUCTION}

Orthoptera are well known and important pests at many parts of the world but especially in terrestrial habitats of warmer regions. Their consumption in temperate grasslands may be annually $3-5 \%$ of the plant production (Ingrisch and Köhler, 1998 in Antonatos et al., 2013). In most cases, they are polyphagous and relating to the climatic and vegetation conditions can cause significant economic damage in various crops. Generally, cereals, vegetables, industrial crops, fruit trees and fabaceous vegetation and crops are their host plants (Smith and Holmes, 1977 in Antonatos et al., 2013; Jonson and Mündel, 1987 in Antonatos et al., 2013; Blanchet et al., 2012; Ovsyannikova and Grichanov 2015). Although, the diversity of Orthopterans is considerable, merely few species can attain the pest status. Regarding Mediterranean countries, economically important species are Dociostaurus maroccanus (Thunberg, 1815), some Calliptamus spp. and Tettigonia viridissima (Linnaeus, 1758) (Pelekasis, 1976 in Antonatos et al., 2013; Latchininsky, 1998 in Antonatos et al., 2013; Blanchet et al., 2012). In Central and Western Europe both, their diversity and the caused damage are less (Nagy, 1988) even some species - because of the habitat destruction - are in vulnerable situation (Cooper et al., 2012; Anonymous, 2015). Regarding their feeding habits, not each Orthoptera are herbivorous. Species of the family Tettigoniidae are omnivorous with predaceous preference but they consume also plants (Nagy, 1988; Ovsyannikova and Grichanov, 2015).

Great green bush-cricket (= GGBC), . . viridissima is a serious pest of cereals, potatoes, grapevines and other annual crops (Gentry, 1965 in Antonatos et al., 2013; Pelekasis, 1976 in Antonatos et al., 2013). According to recent Greek data, its damage was important in vines, cottons and potatoes but the last crop suffered the most loss (Antonatos et al., 2013). In the following, this species is briefly described.

\section{Distribution and habitats}

The species lives in Europe, Northern Africa, Middle East, Russia, Afghanistan, Northern India, Pakistan, Mongolia, and Western China (Kaltenbach, 1964; Nagy, 1988; Szövényi, 2002; Ovsyannikova and Grichanov, 2015).

Its habitats include shrubs, woodland, heath, brambles, grassy margins of wet woodland, humid and semihumid pasture, meadow, riverside and marshy grasslands, cultivated land, fallow and cereal field edge. At forest margins, it prefers the lower part of crones. It can be occur above $15 \mathrm{~m}$ up to $1830 \mathrm{~m}$ above sea-level. (Nagy, 1988; Szövényi, 2002; Antonatos et al., 2013; Ovsyannikova and Grichanov, 2015).

\section{Morphology}

Adults' body length is $27-39 \mathrm{~mm}$, their colour is grass green, sometimes with some brownish shade. Dorsally on head, pronotum and elytra a sometimes indefinite light-brown, reddish or black stripe runs longitudinally. Legs are green, on hind femora black spines, some green at base. Male cercus has a large pointed inner tooth and its subgenital plate is posteriorly broadly emarginated. Ovipositor curved slightly towards the tip, its length does not exceed that of elytra (Nagy, 1988; Holst, 1997; Roques and Jourde, 2013; Ovsyannikova and Grichanov, 2015). 


\section{Life history}

Postembryonic development is epimorphosis (monometabolia). The species has one generation a year and overwinters in the soil as an egg. Female lays eggs - stuck to each other by two and four - in the soil at a depth of two cm. Total number of eggs is 70-100. Nymphs appear in spring, developing time is 50-70 days with 5-7 instars. The nymphs are green, with a brown or reddish dorsal stripe, differing from adult as being wingless (Nagy, 1988; Holst, 1997; Ovsyannikova and Grichanov, 2015).

\section{Damage and economic significance}

T. viridissima is omnivorous. Its damage area includes commonly the southern perhaps central region of Europe where field cultures mainly wheat, barley, cotton, hemp, maize, millet, Italian millet, soya, alfalfa, various leguminous cultures, sunflower, sesame, poppy, potato, tobacco are attacked. It feeds on leaves, shoots, unripe grains and bolls. GGBC prefers fruit and ornamental cultures such as peach, plum, walnut, melon, roses and Lilium sp., damaging buds, leaves, and ripe fruits. It harms leaves and young shoots on grapevine and blackberry and also leaves of oak and other deciduous trees can be damaged. The observed damage is more significant in drought-stricken years. It can feed also on various small insects (flies, minor caterpillars, etc.) and mites. In custody, also cannibalism was observed as it fed on weaker individuals and nymphs (Zacher, 1949 in Nagy, 1988; Nagy, 1988; Schiemenz, 1989; Bistrichanov et al., 2010; Atanasova et al., 2013; Ovsyannikova and Grichanov, 2015).

\section{Control}

Control measures involve mainly insecticide treatments before oviposition if necessary (Anonymous2, 2015; Ovsyannikova and Grichanov, 2015. If pest population is high early season chemical treatment of field margins may be advisable depending on the economic threshold (ET). If crops are under drought stress, the ET value may need to be lowered (Deneke and Keyser, 2011). In the US, beta-cyfluthrin, lambda-cyhalothrin, gammacyhalothrin, zeta-cypermethrin and carbaryl were suggested against grasshoppers (locusts) in pastures and forage crops in 2015 (Anonymous2, 2015). Also cultural and mechanical control can be practiced. It is advisable to modify the environment to take advantage of the vulnerable timing of the grasshopper's life cycle to reduce or eliminate pest populations. Tillage of summer fallows may discourage pest's egg laying in the autumn.

The red-footed falcon (Falco vespertinus (Linnaeus, 1766) consumes T. viridissima mainly in the breeding period. GGBC is the 11th most frequent prey in the diet of F. vespertinus in Hungary (Haraszthy et al., 1994).

The objective of this study was to assess the observed $T$. viridissima damage in maize and to conclude to the agricultural consequences.

\section{MATERIALS AND METHODS}

The surveyed sites were found at Máriabesnyő about $25 \mathrm{~km}$ from Budapest. Both fields belonged to the Szent István University and localised near the railway line running towards Budapest. Field1 was surrounded by dense hedges and a field path along a tree row of Robinia pseudoacacia L. Field2 was localised at the other side of the path and bordered by two hedges, another path and a row of deciduous trees consisted of Acer campestre L., Acer pseudoplatanus L., Acer platanoides L., Celtis occidentalis L., Cornus sanguinea L., Juglans regia L., Fraxinus ornus L., Malus domestica L., Prunus serotina Erh., Populus nigra L., R. pseudoacacia L., and Rosa canina L. Across the tree row, there was a 7.7 ha alfalfa field.

Information on the localities and the survey are showed in Table 1.

Characteristics of the sites and the maize stands in Máriabesnyő (2015)

\begin{tabular}{|c|c|c|c|c|}
\hline Sites & $\begin{array}{c}\text { Geographical } \\
\text { position and } \\
\text { altitude (m) }\end{array}$ & $\begin{array}{c}\text { Field } \\
\text { size } \\
\text { (ha) }\end{array}$ & $\begin{array}{c}\text { Time } \\
\text { of } \\
\text { survey }\end{array}$ & $\begin{array}{c}\text { Average } \\
\text { plant height } \\
\text { (cm) }\end{array}$ \\
\hline Field1 & $\begin{array}{c}47^{\circ} 35^{\prime} 51^{\prime \prime} \mathrm{N} \\
19^{\circ} 22^{\prime} 28^{\prime \prime} \mathrm{E} \\
207\end{array}$ & 2,7 & 06.15. & 175.4 \\
& 207 & & & \\
\hline Field2 & $\begin{array}{c}47^{\circ} 35^{\prime} 53^{\prime \prime} \mathrm{N} \\
19^{\circ} 22^{\prime} 05^{\prime \prime} \mathrm{E} \\
212\end{array}$ & 10,7 & 06.15. & 178.7 \\
& 212 & & & \\
\hline
\end{tabular}

Survey method: Four times 25 plants were examined from the field border diagonally, along a transect line. Plants were chosen randomly after making five steps. There were 30 steps between repetitions. Number of cricket's chewing as well as that of GGBC individuals was noted. Field1 was monitored until the harvest in the late of August (22.08.) (Figure 1). 
Both fields were overgrown with weeds such as Artemisia vulgaris L., Ambrosia artemisiifolia L., Cannabis sativa var. spontanea L., Chenopodium album L. and Atriplex tatarica L. The weeds hampered even the moving in the fields. No pesticides were applied.

Evaluation: T. viridissima infestation of the fields was compared on the basis of the number of damaged plants. Data were examined by two-sample t-test and one way ANOVA of correlated samples (http://vassarstats.net/).

Figure 1: Field1 Máriabesnyő (2015)

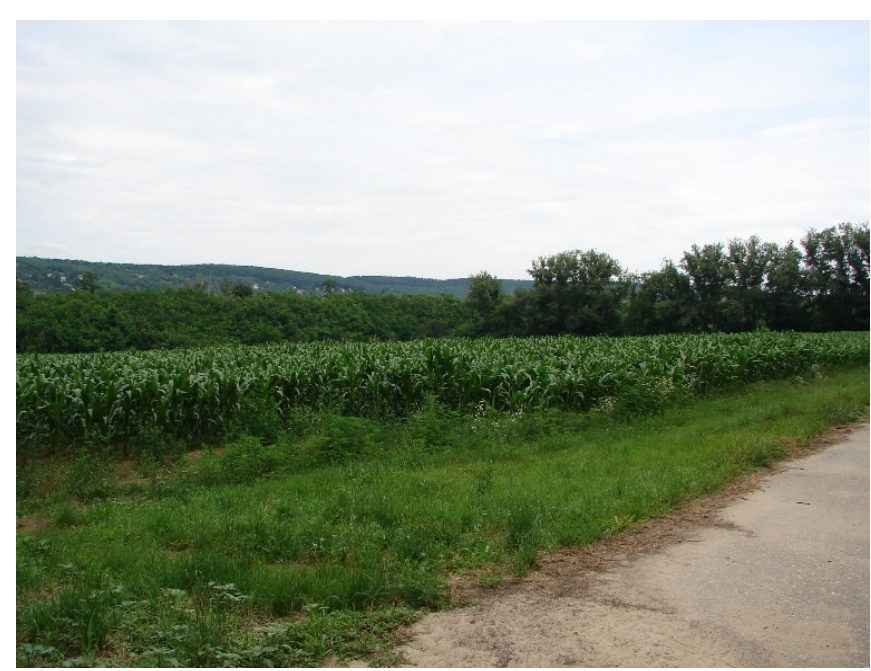

\section{RESULTS AND DISCUSSION}

Results are presented in the Table 2 and 3. According to the results, occurrence and damage of T. viridissima were slight at both sites.

Number of damaged plants (Máriabesnyő, 2015)

\begin{tabular}{|l|c|c|}
\hline Sites & $\begin{array}{c}\text { Average number of damaged } \\
\text { plants } \\
(\%)\end{array}$ & $\begin{array}{c}\text { Confidence } \\
\text { interval } \\
\mathrm{P}=0.95\end{array}$ \\
\hline Field1 & $1.25(1.25)$ & 2.00 \\
\hline Field2 & $5.25(5.25)$ & 5.41 \\
\hline
\end{tabular}

Two-sample t-test did not showed significant difference between values at $\mathrm{p}=0.05, \mathrm{t}=-2.2$, $\mathrm{df}=6$. (http://vassarstats.net/).

Number of damaged plants at field1 during the season (Máriabesnyö, 2015)

\begin{tabular}{|l|c|c|}
\hline Date & $\begin{array}{c}\text { Average number of damaged plants } \\
(\%)\end{array}$ & Standard deviation \\
\hline 06.21. & $2.00(2.00)$ & 0.00 \\
\hline 06.27. & $2.75(2.75)$ & 1.89 \\
\hline 07.04. & $1.75(1.75)$ & 1.50 \\
\hline 07.11. & $2.25(2.25)$ & 1.26 \\
\hline 07.18. & $0.75(0.75)$ & 0.50 \\
\hline
\end{tabular}

One way ANOVA computed no significant difference among values at $\mathrm{p}=0.05, \mathrm{df}=4, \mathrm{~F}=1.83$.

(http://vassarstats.net/).

During the season two nymphs and a female T. viridissima were observed at field1 on 15.06. and 27.06., respectively (Figure 2 and 3).

The number of chewing on one injured plant varied between one and six and its size between one and eight $\mathrm{cm}^{2}$. However, the damage was not of importance and did not influence either the yield or the survival of crops involved. Continual monitoring at field1 showed a low and stable infestation level until 18.07. After this date no more fresh damage was detected (Figures 4 - 6). 
The number of objective investigations on yield losses caused by Orthoptera is not high. Antonatos et al. (2013) assessed the leaf area $\left(\mathrm{cm}^{2}\right)$ consumption of three species, viz. Calliptamus barbarous (Costa, 1836), Dociostaurus maroccanus (Thunberg, 1815), and T. viridissima. Females consumed more than males in case of all species and $T$. viridissima females ingested at $25{ }^{\circ} \mathrm{C}$ the utmost quantity - compared to the other orthopteran species - of vine, cotton and potato 24, 23 and $60 \mathrm{~cm}^{2}$ leaf area, respectively.

Figure 2: Tettigonia viridissima nymph at field1 (Máriabesnyő, 2015)

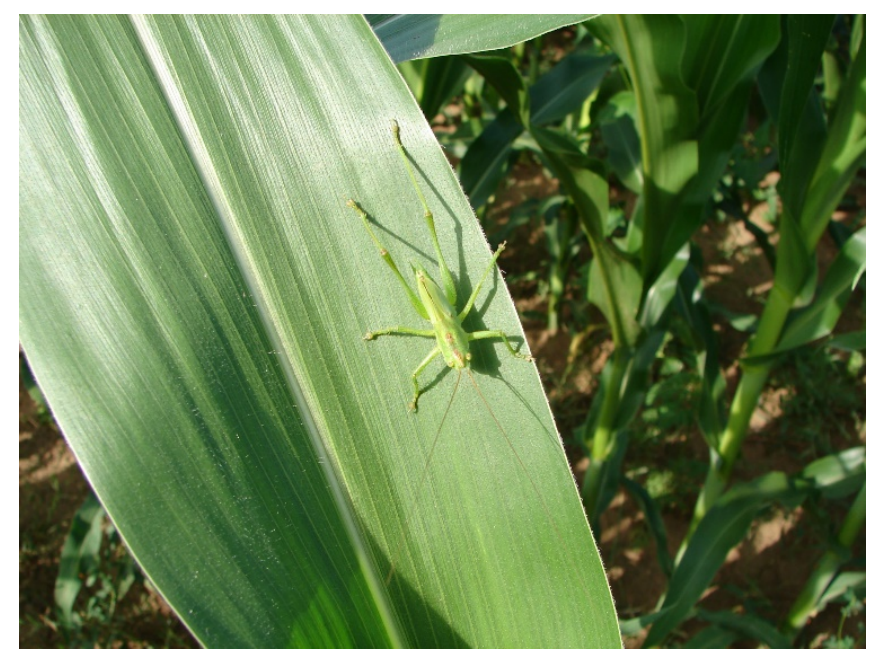

Figure 3: Tettigonia viridissima female at field1 (Máriabesnyő, 2015)

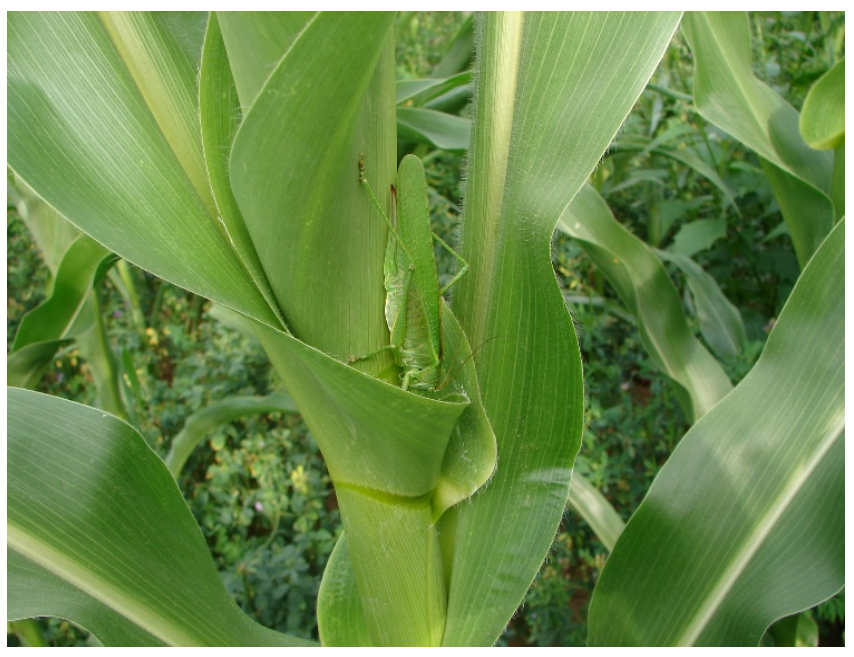

Rising temperature $\left(30^{\circ} \mathrm{C}\right)$ increased significantly the leaf area consumption which was about $25-40 \%$ higher than the former data (Antonatos et al., 2013). This shows clearly that higher temperature increases the quantity of consumed plant tissue and so the yield loss. Thus, damage of Orthoptera is higher in Mediterranean or subtropical areas than in the Central European or more northern regions. This phenomenon can be observed also in size variables of $T$. viridissima males collected in four European regions (Spain, Southern France, Central France and UK). Body length, wing length and width of GGBC males continually decreased from south towards north and the difference among the values often was significant (Cooper et al., 2012).

In Bulgaria, T. viridissima attacked the green plant parts, flowers and seeds of coriander (Atanasova et al., 2013) and bit off the handle of flowers of Lilium rhodopaeum (Bistrichanov et al., 2010). The severity of the damage has not been commented. In Hungary, slight damage in vines, tobaccos, cereals, fruit trees, melons, roses (Zacher, 1949 in Nagy, 1988) and in maize, alfalfa and clover stands (Nagy, 1988) were observed however it was stressed that mass outbreak or explicit damage of GGBC have not been perceived (Nagy, 1988). Regarding the continual warming impact of climate change, damage and yield loss of $T$. viridissima could be more severe in the future. 
Figure 4: Chewing damage at field1 (Máriabesnyő, 2015)

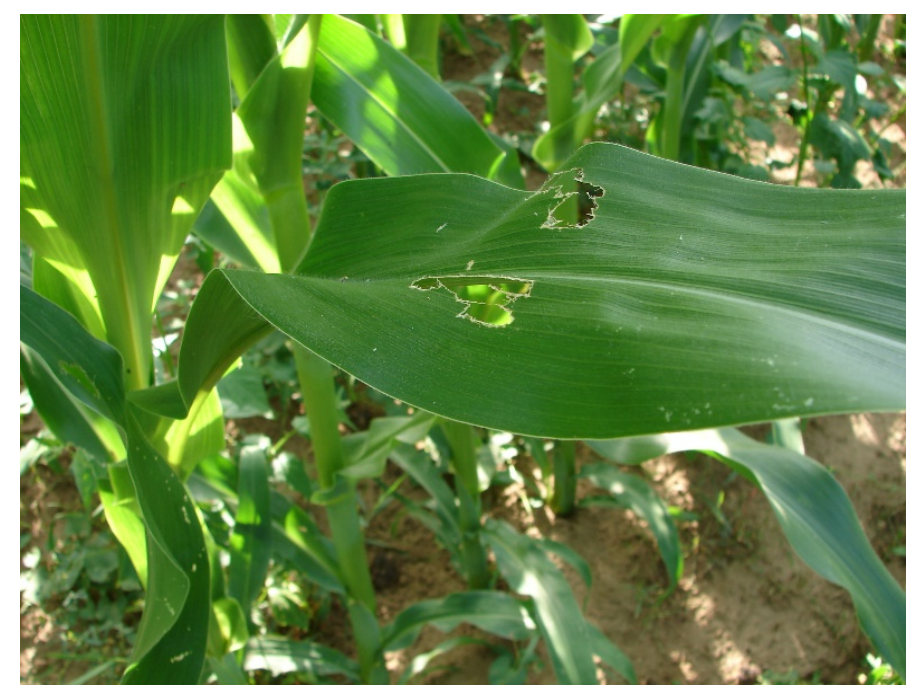

Figure 5: Chewing damage at field1 (Máriabesnyő, 2015)

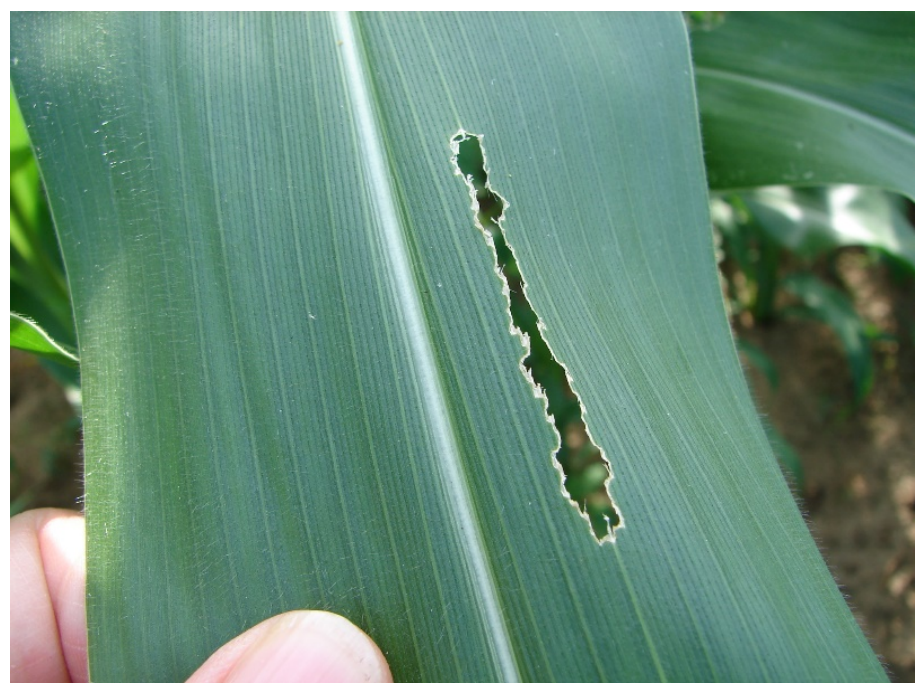

Figure 6: Chewing damage at field1 (Máriabesnyő, 2015)

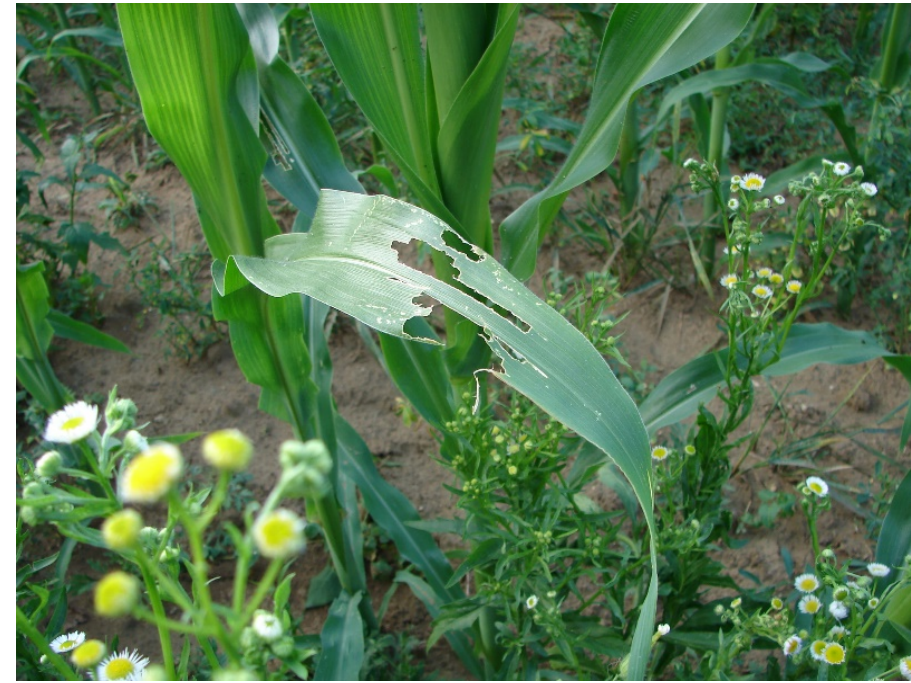




\section{REFERENCES}

Anonymous (2015): Heuschrecken in Hamburg. Rote Liste und Artenverzeichnis. http://www.hamburg.de/contentblob/135208/data/heuschrecken.pdf

Anonymous2 (2015): Pastures and forage crops. Insect and weed control recommendations for 2015. Alabama A \& M and Auburn Universities, http://www.aces.edu/pubs/docs///IPM-0028/IPM-0028.pdf

Atanasova, D., Maneva, V., Dacheva, S., Atanassov, A.(2013): Phytosanitary monitoring of coriander crops in south -east Bulgaria. Povrćarstvo, ukrasno, aromatično i ljekovito bilje. 48. hrvatski i 8. međunarodni simpozij agronoma | Dubrovnik | Hrvatska http://sa.agr.hr/pdf/2013/sa2013_p0413.pdf semmi adat nincs a kárról

Antonatos, S.A., Emmanuel, N.G. and Fantinou, A.A. (2013): Effect of temperature and species of plant on the consumption of leaves by three species of Orthoptera under laboratory conditions. Eur. J. Entomol. 110 (4): 605-610.

Bistrichanov, S., Ivanova, I., Kaninski, A., Kadhum, E. (2010): Phytosanitary monitoring of Lilium rhodopaeum Delip. in Bulgaria. Journal of Environmental Studies [JES] 4:15-17. http://www.jes.sohag.edu.eg/VOL.IV/3.pdf

Blanchet, E., Lecoq, M., Sword, G.A., Pages, C., Blondin, L., Billot, C., Rivallan, R., Foucart, A., Vassal J.M., Risterucci, A.M. \& Chapuis, M.P. (2012): Population structures of three Calliptamus spp. (Orthoptera: Acrididae) across the Western Mediterranean Basin. Eur. J. Entomol. 109 : 445-455.

Cooper, E.M., Lunt, P.H., Ellis, J.S., Knight, M.E. (2012): Biogeographical patterns of variation in Western European populations of the great green bush-cricket (Tettigonia viridissima; Orthoptera Tettigoniidae). J. Insect. Conserv.

https://www.researchgate.net/publication/257580225_Biogeographical_patterns_of_variation_in_Western_European_populations_of_th e_great_green_bush-cricket_(Tettigonia_viridissima_Orthoptera_Tettigoniidae)

Deneke, D.L. and Keyser, J. (2011): Integrated pest management strategies for grasshopper management in South Dakota. South Dakota State University/USDA, Extension Extra 8131, pp. 4. http://pubstorage.sdstate.edu/AgBio_Publications/articles/ExEx8131.pdf

Haraszthy L., Rékási J., Bagyura J. (1994): Food of the red-footed falcon (Falco vespertinus) in the breeding period. Aquila 101: 93-110.

Holst, K.Th. (1997): The Saltatoria (Bush-crickets, crickets and grasshoppers) of northern Scandinavia. (Fauna Entomologica Scandinavica) E.J. Brill / Scandinavian Science Press Ltd. Leiden-Copenhagen, 9-127.

Kaltenbach, A. (1964): Die Mantidea und Ensifera der Österreichischer Karakorum Expedition 1958. Ann. Naturhistor. Mus. Wien. 67, 443445.

Ovsyannikova, E.I., Grichanov, I.Ya. (2015): Tettigonia viridissima. Interactive Agricultural Ecological Atlas of Russia and neighbouring countries. Economic plants and their diseases, pests and weeds. http://www.agroatlas.ru/en/content/pests/Tettigonia_viridissima/

Nagy B. (1988): Zöld lombszöcske (Tettigonia viridissima Linné). In: Jermy T. and Balázs K. (eds): A Növényvédelmi állattan kézikönyve. 1. Akadémiai Kiadó, Budapest, pp. 215-216.

Roques, O. et Jourde, P. (2013): Clé des Orthoptères de Poitou-Charentes. Poitou-Charentes Nature, Fontaine-le-Comte, pp. 92.

http://www.poitou-charentes-nature.asso.fr/IMG/pdf_Cle_Orthopteres_PCNV1-1.pdf

Schiemenz, H. (1989): Tettigoniidae. In: Stresemann, R., Hannemann, H-J., Klausnitzer, B. and Senglaub, K. (editors): Excursionsfauna für die Gebiete der DDR und der BRD. Band 2/1, Wirbellose, Insekten - Erster Teil. 8. Auflage, Volk und Wissenschaft Vokseigener Verlag, Berlin. p. 109-110.

Szövényi G. (2002): Qualification of grassland habitats based on their Orthoptera assemblages in the Köszeg Mountains (W-Hungary). Entomol. Exp. Appl. 104: 159-163.

VassarStats 2014. Website for Statistical Computation: http://vassarstats.net/

\section{András Bozsik: Tettigonia viridisssima nymph on maize (aquarelle)}

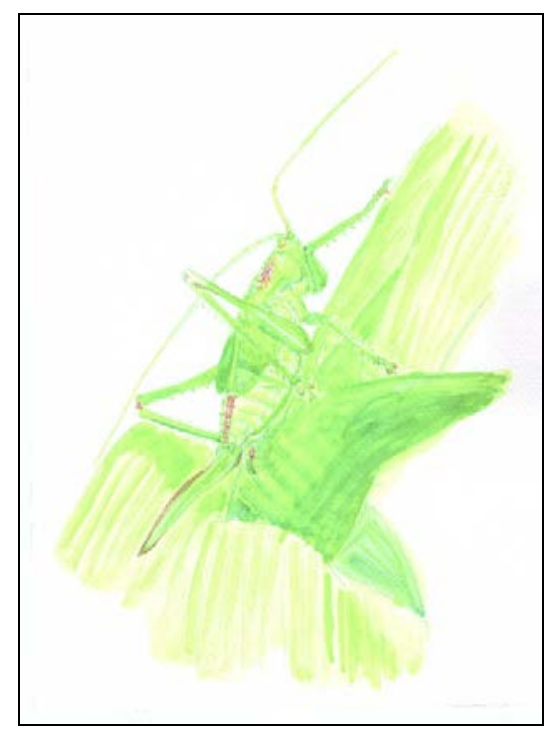

